\title{
Unique challenges and opportunities for northeastern US crop production in a changing climate
}

\author{
David W. Wolfe ${ }^{1}$ (D) Arthur T. DeGaetano ${ }^{2}$ • \\ Gregory M. Peck ${ }^{1} \cdot$ Mary Carey $^{3} \cdot$ Lewis H. Ziska $^{4}$. \\ John Lea-Cox ${ }^{5}$ - Armen R. Kemanian ${ }^{6}$. \\ Michael P. Hoffmann ${ }^{7}$ - David Y. Hollinger ${ }^{8}$
}

Received: 16 November 2016 / Accepted: 25 October 2017 /Published online: 13 November 2017

(C) The Author(s) 2017. This article is an open access publication

\begin{abstract}
Climate change may both exacerbate the vulnerabilities and open up new opportunities for farming in the Northeastern USA. Among the opportunities are double-cropping and new crop options that may come with warmer temperatures and a longer frost-free period. However, prolonged periods of spring rains in recent years have delayed planting and offset the potentially beneficial longer frost-free period. Water management will be a serious challenge for
\end{abstract}

This article is part of a Special Issue on 'Vulnerability Assessment of US Agriculture and Forests developed by the USDA Climate Hubs' edited by Jerry L. Hatfield, Rachel Steele, Beatrice van Horne, and William Gould.

Electronic supplementary material The online version of this article (https://doi.org/10.1007/s10584-0172109-7) contains supplementary material, which is available to authorized users.

David W. Wolfe

dww5@ cornell.edu

1 School of Integrative Plant Science, Cornell University, 133 Plant Science Building, 236 Tower Road, Ithaca, NY 14853, USA

2 Department of Earth and Atmospheric Sciences, Bradfield Hall, Cornell University, Ithaca, NY 14853, USA

3 Farm Service Agency, United States Department of Agriculture, Washington D.C., USA

4 Agriculture Research Service, Crop Systems and Global Change, United States Department of Agriculture, 10300 Baltimore Avenue, Beltsville, MD 20705, USA

5 Department of Plant Science and Landscape Architecture, University of Maryland, 2120 Plant Science Building, 4291 Field House Drive, College Park, MD 20742, USA

6 Department of Plant Science, Pennsylvania State University, 116 Agriculture Sciences and Industry Building, University Park, PA 16802, USA

7 Cornell Institute for Climate Smart Solutions, Cornell University, 105A Rice Hall, Tower Road, Ithaca, NY 14853, USA

8 United States Department of Agriculture Forest Service, 271 Mast Road, Durham, NH 03824, USA 
Northeast farmers in the future, with projections for increased frequency of heavy rainfall events, as well as projections for more frequent summer water deficits than this historically humid region has experienced in the past. Adaptations to increase resilience to such changes include expanded irrigation capacity, modernized water monitoring and irrigation scheduling, farm drainage systems that collect excess rain into ponds for use as a water source during dry periods, and improved soil water holding capacity and drainage. Among the greatest vulnerabilities over the next several decades for the economically important perennial fruit crop industry of the region is an extended period of spring frost risk associated with warmer winter and early spring temperatures. Improved real-time frost warning systems, careful site selection for new plantings, and use of misting, wind machine, or other frost protection measures will be important adaptation strategies. Increased weed and pest pressure associated with longer growing seasons and warmer winters is another increasingly important challenge. Pro-active development of non-chemical control strategies, improved regional monitoring, and rapidresponse plans for targeted control of invasive weeds and pests will be necessary.

\section{Introduction}

The crop production component of the Northeastern US (NE) agricultural economy exceeded US\$9 billion in 2012 (Supplemental Table S1), and includes large wholesale grower-shippers selling product nationally and internationally, as well as thousands of small farm operations selling direct retail. The region ranks high nationally for production of many high-value fruit, vegetable, and specialty crops, such as apples, grapes, fresh market sweet corn, snap beans, cabbage, mushrooms, and ornamental nursery plants. Corn, hay, and other animal feedstock crops that support the approximate US\$12 billion livestock industry of the region (mostly dairy) are another major component of total crop value. Revenue associated with agricultural tourism is also substantial (Northeast Agricultural Tourism Collaboration, http:/www.uvm. edu/tourismresearch). Farmers are on the front lines of coping with climate change, but the direct impacts on crops, pests, and costs of adaptation will have cascading effects beyond the farm gate and throughout the NE economy.

While climate change will create unprecedented challenges for farmers in the region, new opportunities are possible as well, such as developing new markets for crops that may benefit from a longer frost-free period and warmer temperatures (Horton et al. 2014; Wolfe et al. 2011). Prior assessments have provided a broad overview of the fundamental physiological and ecological mechanisms by which climate change and rising carbon dioxide are or will be affecting crop production in the NE and elsewhere (Wolfe et al. 2008; Hatfield et al. 2011). Here, we focus on unique challenges and opportunities for the NE, and adaptation strategies to address climate anomalies of high priority for the region, such as changing rainfall patterns, summer heat stress, and shorter, warmer winters. Knowledge and technology gaps are also addressed.

\section{Methods}

\subsection{Climate change projections}

Novel assessments of climate change impacts specific to NE crop production are based on Coupled Model Intercomparison Project Phase 5 (CMIP5; Taylor et al. 2012) output that has 
been downscaled using the Localized Constructed Analog (LOCA) method (Pierce et al. 2014). Using the LOCA methodology, temperature and precipitation simulations at the coarse resolution of the global models included in CMIP5 are refined to a $0.0625^{\circ}$ spatial resolution grid covering the NE. The decision to adopt this downscaling technique was driven by the planned use of these data in the Fourth (U.S.) National Climate Assessment (http://www. globalchange.gov/nca4).

Currently, there are over 50 models included in the CMIP5 archive; thus, it is unusual for impact studies to include the entire suite of model projections. Here, we use downscaled simulations from a subset of 10 CMIP5 models (Supplemental Table S2) based in part on: (1) their skill in simulating global short and long wave radiation, temperature, wind, and precipitation (Gleckler et al. 2008); (2) their ability to simulate historical climate conditions in eastern North America (Sheffield et al. 2013); and (3) public availability at time of analysis and their representativeness in terms of modeling center and model type (atmosphere-ocean GCM versus Earth system model). Thibeault and Seth's (2015) examination of a subset of 15 models in terms of their ability to simulate Northern US summer precipitation illustrates that the 10 models used here represent the spread and central tendency of this larger subset of models.

The LOCA-downscaled data fields were used to simulate both historical and future conditions in the 1979-2099 time period for Representative Concentration Pathways 4.5 (RCP4.5) and RCP8.5 (Collins et al. 2013). Supplemental Figs. S1-S12 summarize relevant climate change projections used to identify critical vulnerabilities for the region (discussed in Section 3).

\subsection{Recent weather-related crop disaster statistics}

We use crop loss data associated with adverse weather events (excess rainfall, flooding, drought, heat stress, frost, etc.) for the NE for the 2013-2016 period that were reported to the United States Department of Agriculture Farm Service Agency (USDA-FSA) Noninsured Crop Disaster Assistance Program (NAP). These data represent approved loss acreage for crops that are not otherwise insured, as NAP serves as a supplement to private crop insurance. Data prior to 2013 have not been compiled and were not available for this report. While not comprehensive, the 2013-2016 dataset provides a perspective on year-to-year weather variability and impacts for the region.

\subsection{Apple modeling}

The risk of apple frost risk in a changing climate was evaluated using LOCA projections and a phenology model, based on the approach of Cannell and Smith (1986) and chill unit (CU) accumulation beginning in autumn prior to bloom as described by Shaultout and Unrath (1983). Hourly temperatures were inferred from daily maximum and minimum temperatures following Linvill (1990). Once a 1000-CU requirement was met, the accumulation of base $6.1{ }^{\circ} \mathrm{C}$ developmental growing degreedays (GDD) commenced. Phenological data from Geneva, New York, were used determine the occurrence of different stages of development based on post-chilling GDD accumulation. Data from Proebsting and Mills (1978) were then used to determine temperatures at which 10,50 , and $90 \%$ bud kill $\left(\mathrm{T}_{10}, \mathrm{~T}_{50}, \mathrm{~T}_{90}\right.$, respectively) occurred for each developmental stage. 


\section{Climate change vulnerabilities}

\subsection{Increased frequency of high rainfall events}

One of the most pronounced changes in climate in the NE during the past several decades has been a $71 \%$ increase in the frequency of extreme precipitation events since the mid-1990s - the most of any region of the USA (Kunkel et al. 2013). This increase in rainfall extremes is projected to continue through the current century (Supplemental Fig. S5), with the largest proportional increases in the north and at higher elevations. Heavy rainfall can cause reduced yield through root anoxia, and also facilitates the spread of foliar diseases such as late blight (Phytopthera infestans), and incidence of root diseases caused by Pythium, Rhizoctonia, and other fungal species. About a third of all crop losses reported to the USDA-FSA from 2013 to 2016 were associated with excess precipitation when averaged across the entire NE for all years and all crops (Fig. 1). However, there was substantial year-to-year variability, with precipitation being the dominant crop loss factor in all years except 2016, when drought impacts dominated (Supplemental Fig. S14). Data from the Northeast Regional Climate Center summer rainfall for 2013, 2014, 2015, and 2016 averaged 133, 111, 118, and 92\% of the 1981-2010 normal across the 12 states of the NE (http://www.nrcc.cornell.edu/regional/tables/tables.html).

In addition to direct crop damage and increased disease pressure, high rainfall events can lead to soil erosion (Hatfield et al. 2014) and negative environmental consequences of sediment, agricultural chemicals, or animal manure runoff into surface waterways (Hart et al. 2004). Another impact from either high rainfall events or prolonged rainy periods can be delays in planting due to wet or flooded soils. This effectively shortens the growing season, and may offset the trend for longer frost-free periods in the NE. We examined this in more detail with an analysis of model-simulated historical and projected rainfall and last frost date for the Vermont and Pennsylvania regions of the NE for the period 1980-2100 (Fig. 2a, b, respectively). Results suggest that as last frost date is advancing during the century, there is a concomitant increase in the frequency of years with excessive rainfall prior to last frost date (e.g., more than $7.0 \mathrm{~cm}$ in the 21 days just prior to the last frost), which could prevent farmers from planting earlier. This counteracts a potentially positive climate change effect and illustrates why "growing season" and "frost-free period" are not synonymous.

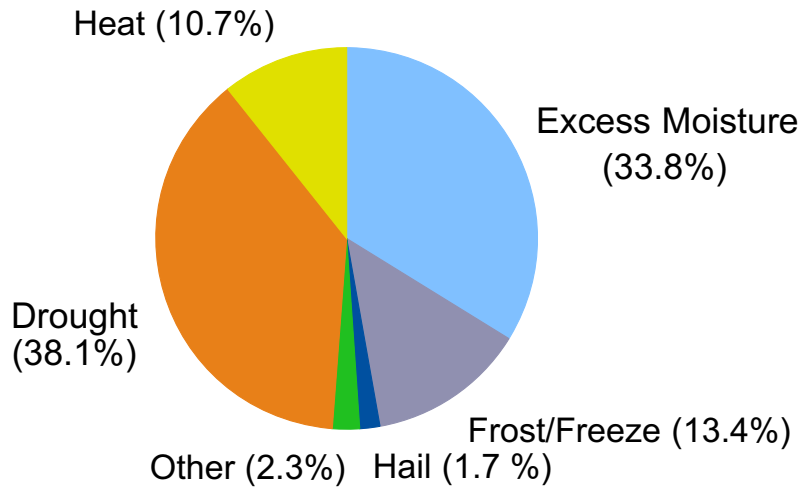

Fig. 1 Primary weather-related crop loss data reported to USDA-FSA, averaged across all crops for the Northeastern USA during the period 2013-2016. See Supplemental Figs S14 and S15 for more detail on yearby-year losses and by crop category 


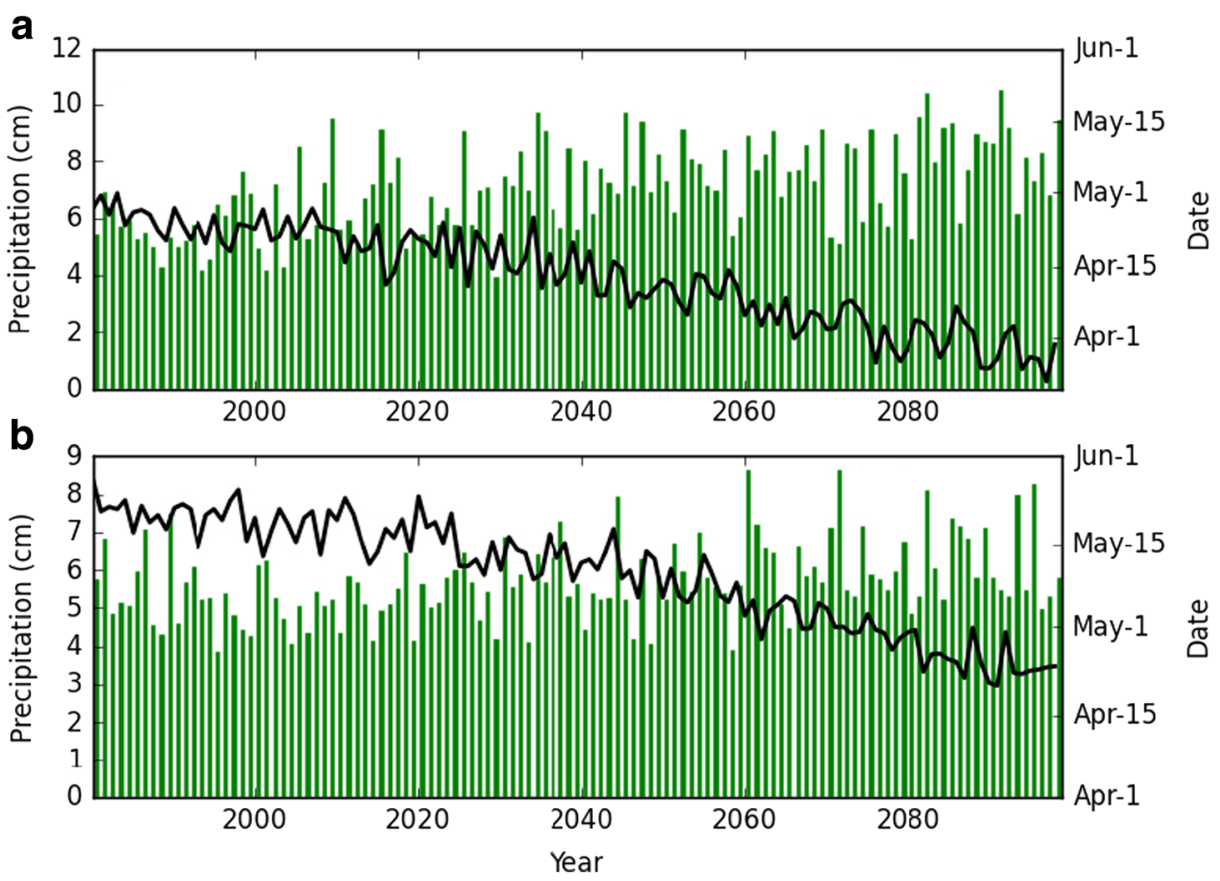

Fig. 2 Last frost date (black line) and rainfall in the 21 days prior to last frost (green bars) for the historical and projected period of 1980-2100 (RCP 8.5 emissions scenario) for Lancaster, Pennsylvania (a) and Burlington, Vermont (b) of Northeastern US Trend is for increased frequency of years with excessive rain (e.g., $>7.0 \mathrm{~cm}$ ) prior to last frost mid- to late-century which could delay planting date despite trend for earlier last frost

For some fresh market vegetable growers, much of their profit is based on reaching market early when the crop's value is greatest, so delayed planting due to wet soils can have substantial negative economic effects. Farmers can try to circumvent this by entering the field even when wet, but use of heavy farm equipment on wet soils leads to soil compaction which subsequently reduces soil water holding capacity, water infiltration rates, root growth, and future yield potential (Wolfe et al. 1995).

\subsection{Summer drought}

The NE has a humid climate with precipitation events well distributed through the year. Nevertheless, supplemental irrigation is required in many years to fully meet crop water requirements for maximum yield and quality of high-value fruit and vegetable crops (Wilks and Wolfe 1998; Dragoni and Lakso 2011). About $40 \%$ of all crop losses reported by NE participants to the USDA-FSA between 2013 and 2016 were caused by drought (Fig. 1), with substantial year-to-year variability (Supplemental Figs S14). Projected increases in potential evapotranspiration for the NE in summer months (Supplemental Fig. S4), combined with little change or a decline in projected precipitation in summer months (Supplemental Figs S1-S3), suggests an increased risk of short-term summer drought for the NE unless summer rainfall increases sufficiently to make up for increasing crop water demand (Hayhoe et al. 2007; Wolfe et al. 2011).

The USDA-FSA data averaged across all years in Fig. 1 are skewed by an unusually severe summer drought in 2016 (Ossowski et al. 2017). The USDA-FSA (2016) declared a drought 
disaster area for much of the region, and significant crop losses were reported for rain-fed corn, hay, forage, and other feedstock crops (Ossowski et al. 2017). Other vulnerabilities were revealed. In hardest hit regions such as western New York, even farmers with irrigation reported significant crop losses (> 30\%), due to inadequate irrigation equipment and water supplies (e.g., low stream flows, dry ponds, or wells) to keep up with crop demand (Sweet et al. 2017).

\subsection{Summer heat stress}

Summer heat stress or unusual warm nighttime temperatures during critical growth stages (e.g., reproductive stages) can lead to significant yield reductions in many grain, vegetable, and field crops (Hatfield et al. 2014). Even when production is not affected, short duration of summer heat stress can reduce crop quality and therefore marketable yield of high-value fruits and vegetables (Wolfe et al. 2008). Heat stress accounted for about $11 \%$ of the weather-related crop losses for the NE reported to USDA-FSA in the 2013-2016 period (Fig. 1), with most of these losses being reported for vegetable crops and field crops (Supplemental Fig. S15).

Continued increases in growing season maximum and minimum temperatures (Supplemental Figs S6-S7) will present both challenges and opportunities to NE agriculture. The historical trends in extremely warm nighttime temperatures (Kunkel et al. 2013) are projected to continue throughout the century (Supplemental Fig. S8). Warm nighttime temperatures increase carbon losses through plant respiration and ultimately can have a negative impact on carbohydrate accumulation and therefore yields. Apples, an economically important crop for the NE, are extremely sensitive to high temperature-induced carbohydrate stress when fruits are about $10 \mathrm{~mm}$ in diameter (Lakso and Robinson 2015). This could lead to excessive fruit drop and yield loss with climate change, although an accelerated phenology with warming could lead to fruit size exceeding the sensitive stage earlier when temperatures are still cool. Because warm nighttime temperatures can accelerate phenological stages, radiation capture and yield of grain crops may also be reduced (Abbate et al. 1997).

Although the increase in daytime maximum temperatures in the NE has not changed appreciably in recent decades compared to the increase in nighttime temperatures (Kunkel et al. 2013), climate model projections suggest that there will be a significant increase in both between now and 2100 (Supplemental Figs S9-S10). This can lead to significant increases in days with high temperatures sufficient to negatively affect yield and quality, particularly for cool season-adapted crops currently grown in the region (Wolfe et al. 2008). Apple fruit sunscald (Racsko and Schrader 2012) and bitterpit (Ferguson and Watkins 1989) are examples of high temperature-related physiological disorders that could become more prevalent in the future.

\subsection{Frost and freeze damage}

Northeast USDA-FSA statistics for 2013-2016 indicate that cold damage (including tree fruit, berry crops, and vine crops) was the third leading cause of weather-related crop losses in the NE (Fig. 1, S15). Warmer winter and early spring temperatures accelerate leaf-out and bud development in many fruit crops, exposing them to an extended period of vulnerability to frost damage. High-value tree fruit crops, particularly apples and grapes, are economically important to the NE (Supplemental Table S1), and increased risk of spring frost damage due to climate change is a major concern and potential limiting factor for the future success of these crops. 
Unusually warm temperatures in late winter and early spring across the Eastern USA in 2012 led to record-breaking early flowering of many plant species (Ellwood et al. 2013). In that year, apples bloomed 3 to 4 weeks earlier than the historical average, which was then followed by a series of spring frost events (Horton et al. 2014). Nearly half the New York apple crop was lost, costing growers millions of dollars. Significant damage to apple buds occurred again in spring 2016 after another mild winter, followed by April frost events.

An analysis of recent historical data for apple, grapes, and lilac in the NE documented a trend for earlier bloom of all three species since the 1960s (Wolfe et al. 2005). Using an apple bloom model, we project phenological stages of green tip, tight cluster, and full bloom (as described by Chapman and Catlin 1976) will occur about 15 days earlier by 2100 compared to current bloom dates for Geneva, New York (a representative apple-growing region of the NE) (Supplemental Fig. S13). However, the relationship between climate effects on bloom date and risk of frost damage is complex. Successful flowering in most temperate perennial plants is determined by (1) meeting the winter chill requirement (a period of winter low temperatures required to break endodormancy), (2) winter and spring warming and degree day accumulation to break ecodormancy, and (3) avoiding a spring frost event as buds develop and become vulnerable to cold damage. The latter is a single weather event and a threshold response. All three of these factors will be greatly influenced by projected climatic changes.

In an apple phenology modeling study in Germany, Hoffmann and Rath (2013) found a decrease in frost risk for flowers in six out of seven model projections with the A1B emissions scenario despite an acceleration of first bloom date of 5.5 days $\mathrm{C}^{-1}$. In contrast, a recent and more generic modeling study using the new Community Earth System Model Large Ensemble project and Extended Spring Indices (Labe et al. 2016) concluded that spring frost risk could increase through mid-century due to lack of synchrony in the advance of first bloom and the advance of last frost date.

We conducted a modeling study for the NE (Fig. 3) and found a small increase in frost risk for some apple flower phenological stages (e.g., bloom) within the next three decades (2010 2039), followed by a decline in frost risk after mid-century. This non-linear trend is likely due to the magnitude of warming by mid-century and relatively few years with risk of temperatures below the lethal freeze damage threshold after mid-century.

Another cold damage risk for perennial fruit crops is midwinter-freeze damage. This occurs when severe cold temperatures are preceded by warm fall or early winter temperatures that delay winter hardening or if warm temperatures occur midwinter, causing the plants to lose hardiness. Such winter cold events resulted in millions of dollars of losses in the New York Finger Lakes wine region during the winter of 2003-2004 (Levin 2005) and again in the winter of 2013-2014 (Martinson et al. 2014), and for peaches in the winter of 2015-016, resulting in a complete crop loss for most of the peach orchards in northern parts of the NE region.

\subsection{Increasing insect and disease pressure}

Warmer winters, hotter summers, longer frost-free seasons, less snow cover, and more precipitation events, alone or as interacting factors, are changing the establishment, spread, and competitive ability of insect, disease, and weed pests within the NE. Longer, warmer summers can lead to more insect generations per season, greater overwintering survival, and a potential decoupling of insect pests and their natural enemies. Rising temperatures have contributed to the northward expansion of European corn borer and Western corn root worm (Diffenbaugh et al. 2008), and invasive insects in the NE, such as hemlock wooly adelgid 


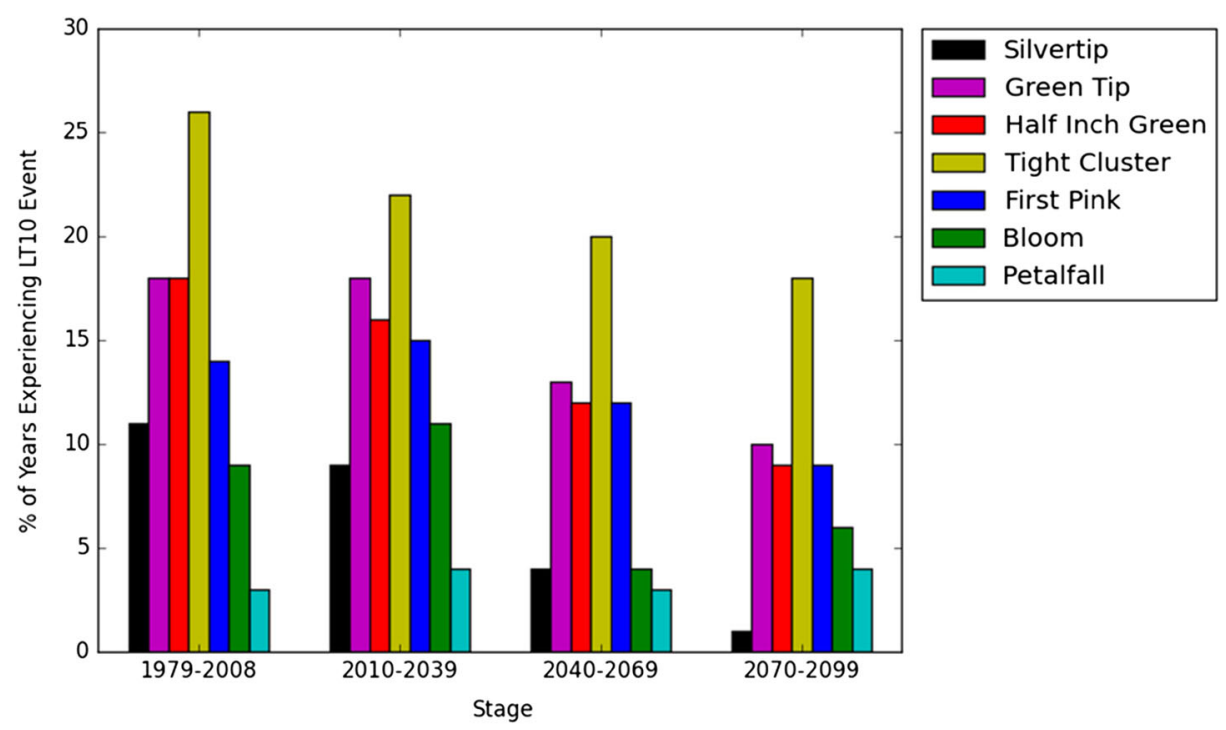

Fig. 3 Percentage of years experiencing a lethal frost event resulting in 10\% apple flower bud damage (LT10) during seven phenological stages from Silvertip (budbreak) to Petalfall (anthesis). Frost risk represents the percentage of model-years (10 models $\times 30$ years) in which at least one freeze event occurred during each development stage in each period. During a given year, freeze events can occur for multiple phenological stages. Future periods are based on RCP8.5

(Paradis et al. 2008). Codling moth (Cydia pomonella) is among the most economically important insect pest of apples in the NE, and warmer summer temperatures would likely allow this species to complete a third generation (Hirschi et al. 2012), which could require additional insecticide applications.

Climate change can affect the incidence and severity of crop diseases by affecting the overwintering, growth, and dispersal of pathogens (Coakley et al. 1999). Climate change may also indirectly affect disease by impacts on insect vectors of crop disease, such as flea beetles (a vector for bacterial Stewart's Wilt of corn). In addition, host vulnerability may increase in cases where climate change causes plant environmental stress. Increased frequency of heavy rainfall events and wet soil conditions could favor some root pathogens (Garrett et al. 2006), and accelerate the spread of foliar diseases such as late blight (Phytophythora infestans), an important disease in potato production in the NE that benefits from wet conditions (Kaukoranta 1996; Sparks et al. 2014). On the other hand, in years and regions where climate change leads to drier conditions, disease pressure could be reduced.

\subsection{Increasing weed pressure}

As winters warm, there is a potential northward expansion of suitable habitat for invasive weedy species such as Kudzu (Wolfe et al. 2008) and oriental bittersweet (Dukes et al. 2009). NE weeds that use the $\mathrm{C}_{3}$ photosynthetic pathway, such as lambsquarters, ragweed, and Canadian thistle, have a strong growth response to increasing atmospheric carbon dioxide $\left(\mathrm{CO}_{2}\right)$ concentration that exceeds the response observed for most cash crops (Ziska and George 2004). In addition, elevated $\mathrm{CO}_{2}$ has been found to reduce the efficacy of glyphosate (the most widely used herbicide in the USA) (Ziska et al. 1999). See below for more discussion of $\mathrm{CO}_{2}$ effects. 


\section{Opportunities and adaptation strategies}

\subsection{Direct effects of increasing atmospheric $\mathrm{CO}_{2}$}

Plants take up $\mathrm{CO}_{2}$ via photosynthesis to produce sugars for growth, and thus this greenhouse gas has a potential positive effect on both weeds (as discussed above) and on crop plants. Many early studies conducted under optimal conditions in growth chambers or greenhouses (e.g., Cure and Acock 1986) found that a variety of plants with the $\mathrm{C}_{3}$ photosynthetic pathway generally increase productivity by 20 to $30 \%$ when atmospheric $\mathrm{CO}_{2}$ levels were doubled from current ambient levels and other growth conditions were optimal. Levels of $\mathrm{CO}_{2}$ in 2016 (400 ppm) are projected to increase to 538 and $936 \mathrm{ppm}$ by 2100 under the RCP 4.5 and RCP 8.5 emission scenarios (Meinshausen et al. 2011). The magnitude of response to $\mathrm{CO}_{2}$ are complex, however, and are affected by genotypic variation in capacity to take advantage of higher $\mathrm{CO}_{2}$ for faster growth or improved water use efficiency, and the degree to which other environmental factors (e.g., temperature) or biotic factors (e.g. insect pests) constrain the photosynthetic and growth response (Wolfe et al. 1998; Hatfield et al. 2011). The climate change projections for increasing risk of both too much and too little water, as well as increasing pest pressure and heat stress in the NE, could in some years offset the potential positive " $\mathrm{CO}_{2}$ fertilization" effect on crops. For example, studies with bean (Jifon and Wolfe 2005) and potato (Peet and Wolfe 2000) showed that doubling $\mathrm{CO}_{2}$ concentration did not compensate for yield losses associated with negative heat stress effects on reproductive development.

\subsection{Opportunities with a longer frost-free period and warmer temperatures}

While climate change will add to the physical and economic challenges of farming in the NE, there are likely to be new opportunities as well as vulnerabilities, such as developing new markets for new crop options that will come with a longer frost-free period (Fig. S11) and warmer growing season temperatures with greater degree-day accumulation (Fig. S12). The expansion of non-native European (Vitis vinifera) wine grape production in the NE over the past 40 years has benefited from the reduced frequency of severe cold winter temperatures over this time period (Wolfe et al. 2011). European red wine grape varieties such as Merlot and Zinfandel could benefit with additional warming, as could other crops such as Prunus species (e.g., peaches, plums, cherries, etc.), watermelon, and tomato.

Warmer temperatures and longer growing seasons enable an intensification of agriculture provided that water availability is not limiting, and that excessive rains do not delay planting or in other ways shorten the growing season. One of the simplest adaptations to take advantage of this potential opportunity is to plant longer growing season varieties with higher yield potential.

A longer growing period would provide more opportunity for double-cropping. An example would be winter barley or winter wheat followed by soybean, a system already practiced with some limitations in southern portions of the NE, and further south in the mid-Atlantic region of the USA. A longer growing period and milder winters would also expand options for use of non-cash winter cover crops, which provide many ecosystem services, such as reducing soil erosion, nitrogen fixation (with legume species), soil nitrogen capture (e.g., with winter rye, Rich 2008), and increasing soil organic matter (Schipanski et al. 2014). While many farmers in the NE appreciate the potential benefits of winter cover crops, fitting these into the current frostfree period without negatively affecting cash crop production limits use (Groff 2015). 


\subsection{Fruit crop frost protection}

Strategies to avoid damage from spring frost begin with careful site selection, and crop and variety selection and/or diversification. The use of wind machines, helicopters, heaters and overhead sprinklers, and covering systems (such as high plastic tunnels) for frost protection has been reviewed by Poling (2008) and others. For midwinter freezes, approaches might include changes in pruning strategies and mulching to insulate the trunk of young plantings. New decision tools will be required to integrate weather forecasts into early-warning systems for extreme events like winter freeze and spring frost events to help perennial fruit crop growers through a phase of climate change transition that may include increased frequency of winter cold damage risk.

\subsection{Water management}

Climate projections for precipitation (Fig. S1 and Walsh et al. 2014) suggest that compared to regions where significant decline in precipitation is projected, the NE is likely to maintain water supplies sufficient for agriculture. That is, severe hydrological drought - the drying up of lakes, reservoirs, groundwater and other supplies - is not anticipated to become a chronic problem in the region. This could manifest as an opportunity for the region and lead to expansion of agricultural land use. However, the severe drought in the summer of 2016, which led to record-low stream flows, and shallow wells and ponds going dry in some regions, has increased awareness that the NE currently lacks an infrastructure for water supply and/or delivery if droughts become longer-term events (Sweet et al. 2017), and also lacks a comprehensive rapid-response plan and pro-active risk management plans for farmers and surrounding communities for severe drought years.

While many NE fruit and vegetable farmers have some capacity to irrigate, few have the available water or equipment to meet water requirements of all of their acreage during prolonged summer droughts. Also, compared to other regions with historically drier climates, farmer knowledge and utilization of decision tools for optimized irrigation scheduling is less common in the NE. Farming success in the NE will require technologies that integrate sitespecific monitoring with decision tools to adapt to rapid changes in environmental conditions. Because the NE is likely to be vulnerable to increased frequency of both too much and too little water, farmers are faced with complex decisions regarding whether they should adapt by investing in irrigation equipment, a drainage system, or both, and when. Unfortunately, climate model projections for precipitation are less certain than for temperature. In addition to installing irrigation or tile drainage systems, other strategies for dealing with this uncertainty include:

- Purchase new planting or harvesting equipment that can cover more acreage more quickly, as a strategy to complete farm operations within smaller windows of opportunity when field access is not compromised by heavy or prolonged rains.

- Improve farm ditch drainage systems to collect water during wet periods and store this in pond systems for use during dry periods.

- Shift crop production to fields less prone to drought or flooding risk based on soil type, topography, or prior management.

- Increase soil organic matter to maximize water holding capacity (buffering against shortterm drought), enhance water infiltration rate, and improve drainage (buffering against 
flooding damage and maintaining field access). Techniques include reducing tillage, maintaining year-round vegetation coverage, and using manures, composts, and mulches as part of fertility management.

\subsection{Control strategies for new pests, diseases, and weeds}

While we can look to more southern regions for control strategies for weeds and pests moving northward, these may not always be directly transferable or desirable for the NE, particularly if they involve substantial increases in chemical loads to the environment. New policies and regulatory frameworks may become necessary, involving good communication among farmers, integrated pest management (IPM) specialists, and state agencies.

Because specific threats are difficult to project, monitoring of pest populations becomes imperative as the climate changes. Greater vigilance in tracking emerging pest threats, a greater willingness to rapidly respond once their presence is known, and a rethinking of current management and control efforts will be essential. Integrated pest management practices that focus on resilience in dealing with multiple aspects of pest and weed migration, detection, response, and control affected by climate change will be increasingly important.

Given uncertainties regarding seasonal weather patterns and climate change projections, a more diversified farm may be buffered from weather-related crop losses due to pest and weeds. Diversification also provides a pathway for farmers to explore new management options for a changing climate, while minimizing the risks associated with a shift at the whole-farm level.

\subsection{Unintended consequences of agricultural adaptation and intensification}

While longer frost-free period, shifts to longer growing season varieties, cropping systems with year-round production, and positive plant responses to increasing $\mathrm{CO}_{2}$ can have yield benefits, there may also be unintended negative impacts on the environment. A longer growing season and increased plant production often involve a corresponding increase in water, nutrient, and chemical inputs, putting stress on resources and potentially increasing risk of nutrient or pesticide loading to waterways. This could be exacerbated by increased frequency of heavy rain events, and increased use of herbicides, pesticides, or fungicides to cope with increasing and more dynamic weed, pest, and disease pressure. On the other hand, adaptation strategies that involve diversifying production systems to cope with climate uncertainty and building resilience to rainfall uncertainty by improving soil health, and improving IPM strategies to cope with new pest and weed dynamics could have an overall positive environmental impact.

\section{Knowledge and technology gaps}

\subsection{Real-time weather-based systems and sensor networks for monitoring and forecasting stress}

Current guidelines for many agricultural practices are based on outdated observations and the assumption of a stationary climate. Even experienced irrigation managers oftentimes make an incorrect decision (Belayneh et al. 2013). Optimized water, frost, nutrient, and pest management decisions in a changing climate will require high-resolution real-time weather data; 
historical data analytics for the particular farm; farm sensor networks to monitor weather impacts on crops, pest, and soils; and relevant crop, pest, and climate models. One of the central challenges to adaptive management is how farmers gain access to this site-specific information in a timely and efficient way, at the required resolution, and at a reasonable cost. In addition to obtaining relevant data, farmers will benefit from insight through analysis and information on optimum timing of efficient management responses (Bögel 2015). This process can be illustrated as:

Data $\rightarrow$ Information $\rightarrow$ Knowledge $\rightarrow$ Decision-Making $\rightarrow$ Outcomes.

which is facilitated by:

Sensor network hardware $\rightarrow$ software / graphical interfaces $\rightarrow$ advanced analytical tools.

The adoption of ground-based sensor technologies has increased in recent years because these systems provide real-time, site-specific data to farmers, which overcomes the current limitations of satellite- or flight-based systems. Access to reliable, precise data from their own farms provides growers with information to adapt crop management on a daily basis. Wireless networks can upload sensor data from both edaphic and environmental sensors as frequently as 1-min resolution, giving irrigation managers real-time information on plant water use. These systems are also able to automate irrigation applications (Lea-Cox et al. 2013). Research conducted in ornamental production environments indicate that these systems can reduce irrigation water applications between 40 and $70 \%$, along with labor and energy use (Belayneh et al. 2013). These systems have also been shown to lower plant mortality, shorten production times, and reduce pesticide applications (Chappell et al. 2013; Lichtenberg et al. 2013) significantly increasing crop quality and profitability for growers (Saavoss et al. 2016).

\subsection{Integrating climate model projections with decision tools for long-term capital investments}

Regional climate science and modeling research are needed to help farmers discern between adverse weather events that are part of normal variability and those that are indicative of a longterm climate shift warranting adaptation investment. There are some climate factors, such as increased climate variability and increased frequency and clustering of extreme events, that could potentially have severe negative impacts on the agriculture industry, but our current level of certainty about these climate factors is low. While investment in research to improve climate models is essential, we may be decades away from accurately projecting changes in some climate variables at the local level, so adaptation with uncertainty will continue to be a necessity.

While the immediate concern of farmers tends to be decision tools for day-to-day management, many large capital investments involve complex decision with a longer time horizon, such as investing in a new irrigation or drainage system or changing varieties of a perennial fruit crop. For these cases, farmers will require tools for evaluation of several climate change scenarios in relation to costs, risks, benefits, and strategic timing of various adaptation options.

\subsection{Crops with increased tolerance to climate stresses}

Varieties with improved stress tolerance, or those adapted to take advantage of a longer growing season for increased yield may already be available for some crop species. New molecular-assisted crop breeding strategies may speed development of new genetic types more tolerant of biotic and abiotic stress. However, to date, many such efforts have focused on a few major world food crops such as corn and wheat, while high-value fruit and vegetable crops that 
dominate the NE agriculture economy have received less attention. Breeding perennial fruit crops requires a much longer effort than is required for annual crops. Additionally, it is often more difficult to introduce new varieties of fruit crops because consumers recognize and value specific varieties (i.e., McIntosh apples or Riesling wine grapes). Even for annual crops, changing varieties is not always an easy or low-cost option. New introductions must not only be adapted to the new climate, but also adapted to local soils, farming practices, and meet local market preferences for color, size, flavor, and other quality factors.

Open Access This article is distributed under the terms of the Creative Commons Attribution 4.0 International License (http://creativecommons.org/licenses/by/4.0/), which permits unrestricted use, distribution, and reproduction in any medium, provided you give appropriate credit to the original author(s) and the source, provide a link to the Creative Commons license, and indicate if changes were made.

\section{References}

Abbate PE, Andrade FH, Culot JP, Biindraban PS (1997) Grain yield of wheat: effects of radiation during spike growth period. Field Crops Res 54:245-257

Belayneh BE, Lea-Cox JD, Lichtenberg E (2013) Costs and benefits of implementing sensor-controlled irrigation in a commercial pot-in-pot container nursery. HortTech 23:760-769

Bögel G (2015) Will software eat your food? Digital Transformation of Agriculture. Central European University Business School Working Paper. 29 p. Budapest, Hungary. http://archive.ceu.hu/publications/bogel/2015 /44029. Accessed 06/20/2016

Cannell R, Smith RI (1986) Climatic warming, spring budburst and forest damage on trees. J Appl Ecol 23(1): 177-191

Chapman PJ, Catlin GA (1976) Growth stages in fruit trees-from dormant to fruit set. New York's Food and Life Sci. Bul, New York No. 58

Chappell M, Dove SK, van Iersel MW, Thomas PA, Ruter J (2013) Implementation of wireless sensor networks for irrigation control in chree container networks. HortTech 23:747-753

Coakley SM, Scherm H, Chakraborty S (1999) Climate change and plant disease management. Annu Rev Phytopathol 37:399-426

Collins M et al (2013) The new concentration driven RCP scenarios and their extensions. In Chap 12, Section 12.1.3.1.3. Long-term climate change: projections, constraints, and irreversibilities. IPCC WG1 2013, Cambridge University Press, Cambridge, pp 1045-1047

Cure JD, Acock B (1986) Crop responses to carbon dioxide doubling: a literature survey. Agric Forest Meteor 38:127-145

Diffenbaugh NS, Krupke CH, White MA, Alexander CE (2008) Global warming presents new challenges for maize pest management. Env Res Letters 3(4):044007

Dragoni D, Lakso A (2011) An apple-specific ET model. Acta Hort 903:1175-1180

Dukes JS, Pontiu J, Orwig D, Garnas JR, Rodgers VL, Brazee N, Cooke B, Theoharides KA, Stange EE, Harrington R, Ehrenfeld J (2009) Responses of insect pests, pathogens, and invasive plant species to climate change in forests of northeastern North America: what can we predict? Can J For Res 39(2):231-248

Ellwood ER, Templer SA, Primack RB, Bradley NL, Davis CC (2013) Record-breaking early flowering in the eastern United States. PloS-One 8(1):e54,788. https://doi.org/10.1371/journal.pone.0053788

Ferguson IB, Watkins CB (1989) Bitter pit in apple fruit. Hort Reviews 11:289-355

Garrett KA, Dendy SP, Frank EE, Rouse MN, Travers SE (2006) Climate change effects on plant disease: genomes to ecosystems. Annu Re Phytopathol 44:489-509

Gleckler PJ, Taylor KE, Doutriaux C (2008) Performance metrics for climate models. J Geophys Res: Atmos 113(DO6104):20. https://doi.org/10.1029/2007JD008972

Groff S (2015) The past, present, and future of the cover crop industry. J Soil Water Cons 70(6):130A-133A

Hart MR, Quin BF, Nguyen ML (2004) Phosphorus runoff from agricultural land and direct fertilizer effects: a review. J Environ Qual 33:1954-1972

Hatfield JL, Boote KJ, Kimball BA, Izaurralde RC, Ort D, Thomson A, Wolfe DW (2011) Climate impacts on agriculture: implications for crop production. Agron J 103:351-370 
Hatfield JL, Takle G, Grotjah R, Holden P, Izaurralde RC, Mader T, Marshall E, Liverman D (2014) Agriculture (chapter 6). In: Mellilo J, Richmond TC, Yohe G et al (eds) Third National Climate Assessment. U.S. Global Change Research Program, Washington, D.C

Hayhoe K, Wake C, Huntington T, Luo L, Schwartz M, Sheffield J, Wood E, Anderson B, Bradbury J, DeGaetano A, Troy T, Wolfe DW (2007) Past and future changes in climate and hydrological indicators in the U.S. Northeast. Climate Dyn 28:381-407

Hirschi M, Stoeckli S, Dubrovsky M, Spirig C, Calanca P, Rotach MW, Fischer AM, Duffy B, Samietz J (2012) Downscaling climate change scenarios for apple pest and disease modeling in Switzerland. Earth System Dyn 3:33-47

Hoffmann H, Rath T (2013) Future bloom and blossom frost risk for Malus domestica considering climate model and impact model uncertainties. PlosOne 8(10):e75033. https://doi.org/10.1371/journal.pone.0075033

Horton R, Yohe G, Wolfe DW, Easterling W, Kates R, Ruth M, Sussman E, Whelchel A (2014) Northeast (chapter 16). In: Mellilo J, Richmond TC, Yohe G et al (eds) Third National Climate Assessment. U.S. Global Change Research Program, Washington, D.C

Jifon J, Wolfe DW (2005) High temperature-induced sink limitation alters growth and photosynthetic response to elevated $\mathrm{CO}_{2}$ in beans. J Amer Soc Hort Sci 130(4):515-520

Kaukoranta T (1996) Impact of global warming on potato late blight: risk, yield loss and control. Agric Food Sci Finland 5(3):311-327

Kunkel KE, Stevens LE, Stevens SE, Sun L, Janssen E, Wuebbles D, Rennells J, DeGaetano A, Dobson JG (2013) Part 1. Climate of the Northeast U.S.. NOAA technical report NESDIS 142-1. NOAA, Washington D.C.

Labe Z, Ault T, Zurita-Milla R (2016) Identifying anomalously early spring onsets in the CESM large ensemble project. Climate Dyn (in press) DOI. https://doi.org/10.1007/s00382-016-3313-2

Lakso AN, Robinson TL (2015) Decision support for apple thinning based on carbon balance modeling. Acta Hortic 1068:235-242

Lea-Cox JD, Bauerle WL, van Iersel MW, Kantor GF, Bauerle TL, Lichtenberg E, King DM, Crawford L (2013) Advancing wireless sensor networks for irrigation management of ornamental crops: an overview. HortTech 23:717-724

Levin MD (2005) Finger Lakes freezes devastate vineyards. Wines and Vines, July

Lichtenberg E, Majsztrik J, Saavoss M (2013) Profitability of sensor-based irrigation in greenhouse and nursery crops. HortTech 23(6):770-777

Linvill DE (1990) Calculating chilling hours and chill units from daily maximum and minimum temperature observations. HortSci 25:14-16

Martinson T, Walter-Peterson H, Haggerty L, O'Connell J. (2014). Bud injury on 2014 grape crop. Appellation Cornell. Issue 19 (December 2014). http://grapesandwine.cals.cornell.edu

Meinshausen M, Smith SJ, Calvin KV, Daniel JS, Kainuma MLT, Lamarque J-F, Matsumoto K, Montzka SA, Raper SCB, Riahi K, Thomson AM, Velders GJM, van Vuuren D (2011) The RCP greenhouse gas concentrations and their extension from 1765 to 2300. Climatic Change (Special Issue). https://doi. org/10.1007/s10584-011-0156-Z

Ossowski E, Mecray E, DeGaetano A, Borisoff S, Spaccio J (2017) Northeast drought assessments 2016-2017. National Oceanic and Atmospheric Administration, National Integrated Drought Information System. www. drought.gov

Paradis A, Elinton J, Hayhoe K, Buonaccorsi J (2008) Role of winter temperature on the survival and future range expansion of the hemlock wooly adelgid (Adleges tsugae) in eastern North America. Mitig Adapt Strateg Glob Chang 13:541-554

Peet MM, Wolfe DW (2000) Crop ecosystem responses to climate change-vegetable crops. In: Reddy KR, Hodges HF (eds) Climate change and global crop productivity. CABI, New York

Pierce DW, Cayan DR, Thrasher BL (2014) Statistical downscaling using localized constructed analogs (LOCA)*. J Hydrometeorol 15(6):2558-2585

Poling EB (2008) Spring cold injury to winegrapes and protection strategies and methods. HortSci 43(6):16521166

Proebsting EL Jr, Mills HH (1978) Low temperature resistance [frost hardiness] of developing flower buds of six deciduous fruit species. J Amer Soc Hort Sci 103(2):192-198

Racsko J, Schrader LE (2012) Sunburn in apple fruit: historical background, recent advances and future perspectives. Critical Rev Plant Sci 31(6):455-504

Rich J (2008) Winter nitrogen cycling in agroecosystems as affected by snow cover and cover crops, M.S. Thesis. Cornell University, Ithaca

Saavoss M, Majsztrik JC, Belayneh BE, Lea-Cox JD, Lichtenberg E (2016) Yield, quality, and profitability of sensor-controlled irrigation: a case study of snapdragon (Antirrhinum majus L.) production. Irrig Sci 34: $409-442$ 
Schipanski ME, Barbercheck M, Douglas MR, Finney DM, Haider K, Kaye JP, Kemanian AR, Mortensen DA, Ryan MR, Tooker J, White C (2014) A framework for evaluating ecosystem services provided by cover crops in agroecosystems. Agric Syst 125:12-22

Shaultout AD, Unrath CR (1983) Rest completion prediction model for Starkrimson Delicious apples. J Amer Soc Hort Sci 108(6):957-961

Sheffield J, Barrett AP, Colle B, Nelun Fernando D, Fu R, Geil KL, Hu Q, Kinter J, Kumar S, Langenbrunner B, Lombardo K (2013) North American climate in CMIP5 experiments. Part I: evaluation of historical simulations of continental and regional climatology. J Clim 26(23):9209-9245

Sparks AH, Forbes GA, Hijmans RJ, Garrett KA (2014) Climate change may have limited effect on global risk of potato late blight. Glob Chang Biol 20(12):3621-3631

Sweet S, Wolfe DW, DeGaetano AT, Benner R (2017) Anatomy of the 2016 drought in the Northeastern United States: implications for agriculture and water resources in humid climates. Agric Forest Meteor 247:571-581

Taylor KE, Stouffer RJ, Meehl GA (2012) An overview of CMIP5 and the experiment design. Bull Am Meteorol Soc 93(4):485-498

Thibeault JM, Seth A (2015) Toward the credibility of Northeast United States summer precipitation projections in CMIP5 and NARCCAP simulations. J Geophys Res Atmos 120(19)

USDA-FSA. 2016. USDA designates 15 counties in New York as primary natural disaster areas with assistance to producers in Pennsylvania. USDA Farm Service Agency Release No. 0095.16. Sept 15 2016. http://www. fsa.usda.gov/news-room/emergency-designations/2016/ed_2016_0825_rel_0095

Walsh J, Wuebbles D, Hayhoe K, Kossin J, Kunkel K, Stephens G, Thorne P, Vose R, Wehner M, Willis J (2014) Our changing climate (chapter 2). In: Mellilo J, Richmond TC, Yohe G et al (eds) Third National Climate Assessment. U.S. Global Change Research Program, Washington, D.C.

Wilks DS, Wolfe DW (1998) Optimal use and economic value of weather forecasts for lettuce irrigation in a humid climate. Agric Forest Meteor 89:115-129

Wolfe DW, Comstock J, Lakso A, Chase L, Fry W, Petzoldt C, Leichenko R, Vancura P (2011) Chap. 7 : Agriculture. In: Rosenzweig C, Solecki W, De Gaetano A et al (eds) Responding to climate change in New York state. New York Academy of Sciences. Blackwell Pub, Boston, pp 217-254

Wolfe DW, Gifford RM, Hilbert D, Luo Y (1998) Integration of photosynthetic acclimation to $\mathrm{CO}_{2}$ at the whole plant level. Glob Chang Biol 4:879-893

Wolfe DW, Schwartz MD, Lakso AN, Otsuki Y, Pool RM, Shaulis NJ (2005) Climate change and shifts in spring phenology of three horticultural woody perennials in northeastern USA. Internat J Biometeor 49:303-309

Wolfe DW, Topoleski DT, Gundersheim NA, Ingall BA (1995) Growth and yield sensitivity of four vegetable crops to soil compaction. J Amer Soc Hort Sci 120(6):956-963

Wolfe DW, Ziska L, Petzoldt C, Seaman A, Chase L, Hayhoe K (2008) Projected change in climate thresholds in the Northeastern U.S.: implications for crops, pests, livestock, and farmers. Mitig Adapt Strateg Glob Chang 13:555-575

Ziska LH, George K (2004) Rising carbon dioxide and invasive, noxious plants: potential threats and consequences. World Resour Rev 16:427-447

Ziska LH, Teasdale LH, Bunce JA (1999) Future atmospheric carbon dioxide concentrations may increase tolerance to glyphosate. Weed Sci 47:608-615 